\title{
Branding of Isfahan's Handicrafts by Using PCDL
}

\author{
Reza Sepahvand \\ Faculty of Economics and Management's Assistant Professor of Lorestan University

\section{Seyed Najmuddin Mousavi} \\ Faculty of Economics and Management's Assistant Professor of Lorestan University
}

\author{
Ali Sarshoumi \\ Corresponding Author, Master student of Business Administration of Lorestan University
}

\section{Doi:10.5901/mjss.2016.v7n4s1p308}

\begin{abstract}
A brand is more than just a name, as it contains all the relationships that the customer communicates with different features of products. All products are required to build the brands. The main objective of this study is branding of Isfahan's handicrafts. The objective of this research is applicable and its method is data collection by means of descriptive survey. The data collection tool in this research is based on quantitative and qualitative data and contains structured interviews questionnaires of experts and paired comparisons questionnaires. The population of this study is composed of 20 experts of crafts that have been determined by purposive sampling method. Branding process is done through PCDL model that consists of four stages. The results of first stage indicate the determining of Isfahan's handicrafts' products position compared to other competitors through the method of Walker's perceptible positioning. The results of second stage involve identifying the priorities of advertising methods for these products through Analytical Hierarchy method and also introducing a logo for Isfahan's handicrafts. The third stage shows the performance of Isfahan's handicrafts in terms of four dimensions of the Balanced Score Card (BSC) and also aftermost results of this research include presenting the strategies of competitive, defensive, aggressive and conservative through creating analysis matrix of SWOT.
\end{abstract}

Keywords: Branding, PCDL method, handicrafts of Isfahan

\section{Introduction}

Basically, cities have the characteristics and properties that as unique profile are the reputation factor for people of other cities and even countries. Tourism is one of the most important growing industries and tourism industry development requires a comprehensive and proper application to be successful in attracting the International tourists (Dehdashti et al, 2014). In recent decades the tourism industry is remembered as one of the largest and most diverse industry. Many of countries represent this industry as one of the major sources of adding income to them and strive for developing of this industry. Because this industry especially for developing countries earns most of their income from selling natural resources is very important (Ebrahimi et al, 2010). One of the components of historical and cultural attractions and partly man-made is handicrafts of every town or village. Handicrafts are called as a part of art and industry that by using indigenous raw materials and performing basic work that are done by hand and traditional and handy tools cause to build the products that each one showcase the taste, art and the creativity of their creators (Sarami, 2004). Iran's handicrafts in terms of diversity is on top of all the world's countries (Yavari, 2013:15), which can be considered as an important factor to attract tourists, because each work of handicrafts reflecting the historical, social and cultural characteristics of each region and can play a major role in identifying of genuine and indigenous art and culture (Yavari, 2013:66). Therefore the export promotion including the issuance of handicrafts and making currency revenues are basic conditions of economic development. On the other hand, one of the common mistakes in today's business world is launching the product to market with the impression that gaining the assurance of product quality, guarantees its sales success. This is the mistake of many managers, who think that the characteristics of the product or provided services to the customer can determine the victory in the campaign of market competition. They overlook the fact that in the mid-market these are the commercial brands that demand rival rather than the products and services (Bendixen et al, 2004). According to the 
benefits that branding make for organizations and consumers are considered by marketers. A brand is more than a mere name, since it contains all relationships that the customer communicates with different products' features (Maleki Minbash et al, 2015). Also it seems that the handicrafts to take order and to be targeted in marketing and sales requires a kind of branding that in this way by creating different competitive strategies we determine the current position of this industry in the country's economy and try to improve the economic status of handicrafts. Isfahan by having unique monuments as well as a variety of handicrafts has a high potential in the economic use of attracting the domestic and foreign tourists. Isfahan' from ancient times has been the cradle of art and industry and today it is also the largest and the most famous city of art in Iran (Honarfar, 1977, quoted by Serami, 2005). Isfahan's massive capacity of tourism also can be considered as a complement for the city's monuments and souvenirs (Kazemi et al, 2010). Also, another considerable potential of Isfahan is that it was chosen as a city world of handicrafts in 2015. According to the great potential of Isfahan both in the field of tourism and the art of handicrafts and also the need of branding for handicrafts is felt. It seems that despite the emphasis of urban managers, the effort for economical use of mentioned capacities of Isfahan has not been done enough. Thus, this study seeks to find ways to determine the necessary steps for branding of this precious product. This research seeks to answer the questions such as: How is the marketing position of important handicrafts of Isfahan? What are the most appropriate ways to advertise and promote these products? How is the performance rate for handicrafts' different dimensions of Isfahan city? Which are the most appropriate strategies to strengthen brand value of handicrafts of Isfahan city?

\section{Theoretical Literature}

\subsection{Branding}

One of the key tools and factors in marketing and exporting of this product is branding. Market is not the place of products' competition, but it's the scene of facing and the battle of commercial brands (Kotler et al, 2013). Brand is intangible and hidden property of a product or a service that includes many parameters such as: Name, term or phrase, signs, symbols, logos, designs, intellectual experience of customers and consumers, durability in market, originality of copy of non-mere and having a sustainable and persistent trust and credibility with our customers (Ahmadi Zad et al, 2015). Investors found that increasing of economic and strategic value is not related to the real value of a product or service, but this value is related to the mind of active and powerful customers and brand create this value in their minds. The brands' role in recognition of company's product in today's complex and extensive markets is undeniable (Darzban et al, 2015). Branding has become one of the most important aspects of business strategy. Branding is central axis in creating customers value, brand is not only an image but also is a key tool for creating and sustaining competitive advantage (Holt, 2015).

\subsubsection{Branding of PCDL model}

Different modes for branding of products, services and the cities are presented. The model that is used in this study is PCDL model. This model is based on the study of Indian companies is presented by Ghodeswar (2008) and includes four steps: Positioning of the brand, communicating of the brand's message, delivering of the brand's performance and leveraging of the brand's value. Figure one shows the stages of this model.

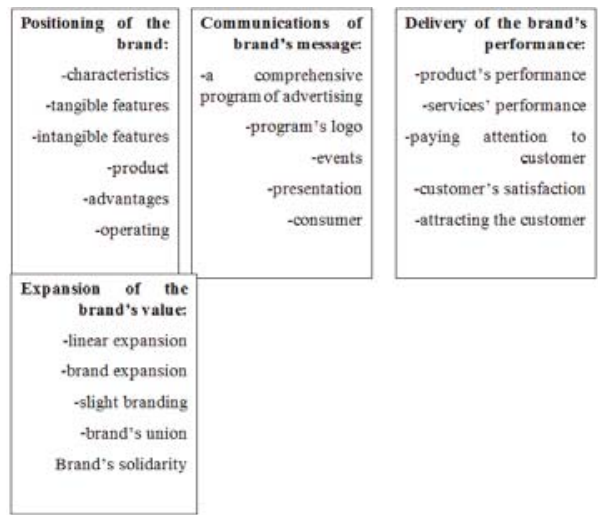

Figure 1: The stages of branding model of PCDL (Ghodeswar, 2008) 


\subsection{Tourism and its relationship with handicrafts}

Tourism industry includes a group of economic activities that in general creates the world's largest industry. Tourism industry provides employment in a wide range \& creates one of the world's largest exports that is one of the motivating factors for investment and growth. Tourism industry is the only industry that its exchanges significantly cause economic dynamism. This industry takes the inactive people of community to work, reduce unemployment and it transforms the potential facilities to active facilities that increase the public welfare (Haghighi et al, 2015). Many tourists stop for shopping the traditional handicrafts of a store. A special section of a tourist experience is handicrafts. Like any product buying the handicrafts satisfies a part of human needs and desires; but handicrafts more than any tourism products plays personal role in tourists' wisdom experience. Handicrafts reflect the local traditions and local and native population's combination in the sectional world. They are also a symbol of the places that tourists visit them. Tourists usually buy the local products as souvenirs or reminder of the places that they have seen and they pay less attention to their aesthetic and functional aspects. Although the official support of good quality of manual work derived from a local tradition can ensure that this product is closely related to handicrafts of the place (Foroughi, 2012).

\section{Background of Former Studies}

Masoumzadeh Zavareh et al (2013) in an article with the title of operational program of branding of the saffron product, by examining the theoretical foundations, comparative studies and using of experts' ideas about saffron industry of Iran, though deep interview and questionnaire have studied the challenges facing the industry and by using SWOT matrix has presented the strategies and operational plans for branding. The research results show that industry in terms of branding hasn't a good situation and includes numerous weaknesses and threats. For this purpose, eight main strategies have been presented in order to develop branding in the industry that the use of them can be the guarantee of improvement of industry situation. Khalili Shojaee and Khodadad Hosseini (20130 in their study presented a unified branding through globalization approach of markets, by using fundamental conceptualization theory in Iran's automotive industry. Finally the unified branding and its formation process were recognized and position of each of the constituent elements of branding pattern was presented in Iran's automotive industry in the form of a model. The extracted model includes factors such as integrated marketing strategy (conditional conditions),special value of identifier (central category), unified communications of identifier (field), stakeholders' commitment (interferer conditions), customers' obligation and commitment (performance and interaction) and branding (outcome). Shafiee et al (2014) in their research with the name of Isfahan is a creative city of handicrafts with tourism development approach, showed that Isfahan according to the defined criteria by UNESCO and the tourists such as Sasaki has the power to be considered as a creative city of handicrafts. By joining the Isfahan to the Network of UNESCO's creative cities has positive outcomes such as presenting a unique image of Isfahan and distinguishing it as a creative \& prosperous tourism destination together with Isfahan's tourism markets and handicrafts. Khorasani Zadeh and Mehrabi (2012) in the article of the role of Isfahan's handicrafts in the development of the Iran's tourism economy and also by studying and identifying of Isfahan's handicrafts have concluded that most exports in Iran are exports of handicrafts and by planning and by managers' attention to this part of industry they can increase the income and the tourist arrivals to the city of Isfahan. Sarami (2005) in his article with the title of Isfahan's handicrafts and its problem said that, Isfahan due to its popularity and centrality, its intelligent and talented and tasteful people and its art history as well as its environmental and geological potential, it should be tried for continuity and prosperity and the problems should be fixed that in addition to the enjoyment of economic and cultural and national and international reputation, this material and industry should be protected and stay firm. Rasul Zadeh and Hassan Nejad (2012) in their research with the title of evaluating and prioritizing of effective methods for attracting the tourists in the province of Khorasan Razavi studied the effective advertising methods for attracting the tourists.

\section{Research Questions}

- What is the status and position of Isfahan's handicrafts in perceptual plan according to the buyers' considered features?

- What are the best ways of advertising and suitable symbol for Isfahan's handicrafts products?

- How is the present performance of marketing of the Isfahan's handicrafts?

- Which are the strategic axes to improve the position and performance of the Isfahan's handicrafts? 


\section{Research Stages}

This research in the form of branding model of PCDL (Ghodeswar, 2008) is done that includes four stages as follows:

Table 1: The stages of conducting research

\begin{tabular}{|l|l|l|l|}
\hline Stage & purpose & method & The studied community \\
\hline First & Positioning the Isfahan's crafts in customers' mind & Perceptual positioning technique & Experts \& customers \\
\hline Second & Presenting logo and determining the best way of advertising & Analytical Hierarchy Process AHP & experts \\
\hline Third & Examining the Isfahan's crafts performance & Balanced Score Card & experts \\
\hline Forth & Presenting the strategy to improve the Isfahan's crafts position & SWOT analysis & experts \\
\hline
\end{tabular}

\section{Research Methodology}

The aim of the present study is functional and data collection method of research is descriptive survey. Data collection method is based on quantitative and qualitative and using semi-structured interviews, experts' questionnaires and questionnaires of paired comparisons. The population of the studied research consisted of 20 handicrafts' experts of Isfahan, ranging from producers of crafts, professors of art university of Isfahan and private university of Foolad Shahr, experts of cultural \& tourism heritage organization, the Union of Isfahan's crafts and the Guilds of Isfahan's crafts' producers that are selected by using of purposive non-probablity sampling method. Also in the research's first stage to identify determiner features of the product at the time of purchase, the semi-structured questionnaire and a survey of 384 customers of Isfahan's crafts and also the single-sample average test of SPSS20 software have been used. In this stage to determine the position of Isfahan's crafts among the competitors, the semi-structured questionnaires that have been completed by experts were used. In the second stage of the research the paired comparisons questionnaire and the Expert Choice11 software to determine the most suitable method of advertising was used. Also to measure the Isfahan's crafts' performance the standard questionnaire of Kaplan and Notron (1996) and single-sampling average test were used. In the final stage of research by using the semi-structured interview, the weak and strong points, opportunities and also the threats around the craft were determined and by use of the SWOT analysis matrix the strategic axes was presented to strengthen the brand value. The questionnaires and interview forms of this research were accepted through content validity confirmation method and professors and experts.

\section{Research Results}

\subsection{First stage of research results (positioning)}

At this stage of the research the Walker's perceptual positioning model (2001) was used. Positioning or perceptual design is a process in which a company decides to create a viewpoint towards its proposed products in the minds of customers that are compatible with their needs and preferences. Perceptual design reflect the criteria that the brands based on them are evaluated by customers and reflect that the product based on these criteria has what which modes (Hair et al, 2002). Perceptual design is a diagram on how to conceive the customers of competitive services. Many companies to help for their positioning course use perceptual design (Love Lock \& Wright, 2006, quoted by Mahmoud et al, 2013). According to this, first the identifying of allowable products of the market was considered that it was tried to identify the competitors of Isfahan's crafts. Table 3 is the introducer of these products.

Table 3: The products of Isfahan's handicrafts \& competitors

\begin{tabular}{|c|l|l|}
\hline Row & Product's name & City (area) or competitor cities \\
\hline 1 & Producing Seal & Shiraz \\
\hline 2 & Weaving carpet & Bakhtiari, Tabriz, Gom, Yazd \\
\hline 3 & etching & Tehran \\
\hline 4 & filigree & Zanjan \\
\hline
\end{tabular}

After determining the total of allowable products the customers tried to identify the determiner features when they are buying the products. By using a questionnaire and survey the important characteristics in terms of customers' attitudes 
were determined and they were important to customers. The determiner criterion of these features to be equal or the average of their importance to be higher than their significance level, were very important. So that the questionnaire includes five-point Likert in which respondents determined the rate of the importance of their desired quality from very low importance to very important matters. The results show the choice of four characteristics including a variety of quality, price and usefulness of the product that in general the characteristics of quality and price gained higher average than the limit of 4 (important) \& thus were determined as determiner features. The results of test are presented in table 4.

Table 4: The related data to single-sampling average test of determiner characteristics of product

\begin{tabular}{|l|c|c|c|c|c|}
\hline Characteristic & average & Significance level & Average difference & Low limit & High limit \\
\hline Quality & 4.40 & 0.028 & 0.400 & 0.05 & 0.75 \\
\hline Various design & 2.50 & 0.000 & -1.500 & -2.19 & -0.81 \\
\hline Price & 4.35 & 0.031 & 0.350 & 0.04 & 0.66 \\
\hline Being functional & 2.55 & 0.000 & -1.450 & -2.05 & -085 \\
\hline
\end{tabular}

After identifying the valid products and determiner features, we turned to examine the comparison of Isfahan's handicrafts products and its competitors according to the determiner features by using nine-point Likert from totally weak to quite strong.

\subsection{The results of second stage (brand communications)}

Logo is a usable graphic element to identify the company, service or product. It is also a distinct sign, symbol or image that has permanent use \& somehow it becomes to a trademark to be protected against misuse of other companies. Logos are immediently recognizable \& act as brand ambassadors; because it undeniably represents a particular organization or business name (brand) (Rousta \& Sabzali, 2012:125). By use of experts opinion a suitable title and sign for Isfahan's crafts is presented in figure 3. Also in order to identify the best methods of advertising by using the prioritization of Analytical Hierarchy Process (AHP) method it's acted out to determine the criteria \& options. One of the most common methods used in decision-making, when decision maker are faced with qualitative standards is Analytical Hierarchy process. This method was presented in the $80^{\text {th }}$ century by Saaty (Asgharpour, 2012:299). In this method the problem is analyzed to smaller sections that to be understandable for the decision-maker and by using of a matrix of paired comparisons, options are compared two by two and according to individuals' preferences, the numbers between one and nine are assigned to them (Tsinidou et al, 2010). Analytical Hierarchy Process is composed of three levels which are respectively target level, the criteria level \& decision options level. Of course in some other cases the under criteria level is added to it. To establish the criteria in this research two advertising theory have been used. The first theory is communications model that it's presented as Blech \& Blech (1980). This model consists of six components (exposure, receiving \& observation, response recognition, attitude, intention, behavior) that according to the research type, the exposure element as one of the criteria is used. Other theories that have been used in research called Crisp technique. The model developed by Mac Carthy \& Perrault (1995), consists of four elements including penetrating, perception, remembering \& being believable that in this study three components of it (penetrating, perception being believable) are used. Aim has used the AIDA model by a tittle change (Hamidi Zadeh \& Yazdani, 2012). Also to establish the options level, the advertising methods of exhibitions, conferences, audio-visual media \& print media have been used (Havaldar, 2013).

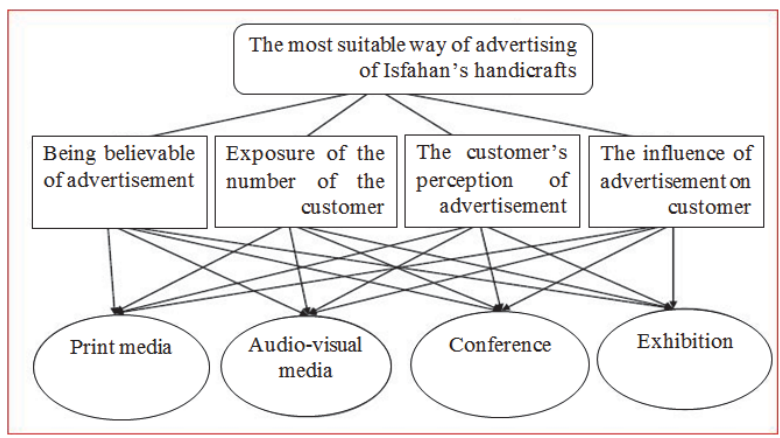

Figure 2: The hierarchical tree of the research to identify and prioritize the most appropriate advertisements for handicrafts 
At first, with the opinions of experts, the priority comparisons between the criteria contained in the study was conducted that the results represented the approximation of priority of these criteria that at the end, the penetration criterion in customer has the most priority. The total results of these comparisons are presented in table 5.

\begin{tabular}{|l|c|}
\hline Criterion & Priority proportion \\
\hline Penetration criterion in customer & 0.263 \\
\hline The customer's perception ratio & 0.259 \\
\hline Exposure of the number of the customer & 0.241 \\
\hline Being believable & 0.236 \\
\hline total & 1 \\
\hline
\end{tabular}

In table 6 the obtained results from comparison of decision options have been presented according to the used criteria in the study. These results reflect the relatively high superiority of audio-visual media for advertisements of Isfahan's handicrafts.

Table 6: The obtained results from comparison of decision options according to the decision criteria

\begin{tabular}{|l|c|}
\hline Option & Priority proportion \\
\hline Audio-visual media & 0.548 \\
\hline Exhibition & 0.199 \\
\hline Print media & 0.131 \\
\hline Conference & 0.123 \\
\hline Total & 1 \\
\hline
\end{tabular}

Also the obtained inconsistency rate from the above paired comparisons is desirable and is 0.01 . The standard rate is an amount of less than 0.01 or ten percent.

\subsection{The results of the third stage of the research}

The third step of PCDL branding model is presenting (the measurement) performance in the field of Isfahan's crafts. In the definition of Nili et al (2002), evaluating the performance as the process of explaining the effectiveness of quality and efficiency of past actions is considered (Mohammadian and Sarshomi, 2016). Balanced Score Card (BSC) is selected to measure the performance presentation of Isfahan's crafts products; Balanced Score Card(BSC) as a tool for evaluating the performance of the organization consists of four perspectives: Financial, customer, business and growth and teaching and learning that for the first time has been introduced by Kaplan \& Norton(1992) (Ghasemi \& Ahmadi, 2013). In this model it is suggested that in addition to considering the measures of financial performance, the customer requirements, business processes must be also considered (Kyarazm, 2014). Balanced Score Card creates a balance between short and long term goals of the organization and convinces the managers that for their actions pay attention to both financial and non-financial and short-term and long-term aspects (Kardnaich, 2015). To measure those dimesions the Kaplan and Norton's Balanced Score Card's standard questionnaire was used and the data gained from the experts' comments of Isfahan's crafts were analyzed by using the single-sample average test (a population average). In the single sample average test, the considered hypothesis about the average about the population average at the level of alpha error is examined. T-score in this test includes the freedom degree of $n-1$ (Momeni \& hayoomi, 2012:59). The research hypothesis is consists of performance average of Isfahan's crafts at the average level. In accordance with the five-point Likert scale the average performance is equal to number three. The items in the used questionnaire have been named respectively: Very poor performance (1), poor performance (2), average performance (3), good performance (4), very good performance (5),

Table 8: The results of t-score test of single-sample to examine the crafts' performance

\begin{tabular}{|l|c|c|c|c|c|}
\hline Variable & average & Significance level & Average difference & Low limit & High limit \\
\hline Customer & 3.0286 & 0.916 & 0.02857 & -0.6743 & 0.7314 \\
\hline Internal processes & 3.4000 & 0.001 & 0.40000 & 0.2867 & 0.5133 \\
\hline Growth \& learning & 3.1429 & 0.546 & 0.14286 & -0.4587 & 0.7444 \\
\hline Financial & 2.2000 & 0.003 & -0.80000 & -1.1512 & -0.4488 \\
\hline
\end{tabular}


Thus we can describe the performance presentation in a way that the dimension of business internal processes that includes seven questions from 25 questions of questionnaire with the average of 3.40 has the highest performance among the four dimensions; although this amount has not the high utility at all. Also in order of the other three dimensions are: the development \& learning dimension (3.014), customer dimension (3.02) \& financial dimension is the only dimension that is measured lower than the average level \& with the average of 2.20 has the weakest performance.

\subsection{The results of four stage of research (reinforcement of brand value)}

At the final stage of research it is proceed to find the strategies to improve the Isfahan's crafts brand. This stage is also called codification of strategic axes. In order to access to intended strategic the matrix of SWOT analysis is used.

SWOT analysis is a useful tool that all classes can present acceptable strategies in various organizational positions and present a way for a business or duty through it. SWOT stands for four words of strengths, weaknesses, opportunities and threats. In this analysis strengths \& weaknesses are internal factors of organization and opportunities and threats are external factors of organization. After that the external factors (opportunities and threats) and internal factors (strengths \& weaknesses) were recognized \& their key factors from non-key factors were distinguished, then it is the time of suggestions. In general, after the combination of four elements mentioned above, in a matrix four kinds of offensive strategy (SO), conservative strategy (WO), competitive strategy (ST) and defensive strategy (WT) are considered as strategic axes to promote the brand of Isfahan's handicrafts.

Table 11: The SWOT matrix of strategic axes to improve the brand of Isfahan's crafts

\begin{tabular}{|c|c|c|}
\hline $\ln$ & $\begin{array}{l}\text { Strong points(S) } \\
\text { *High quality of Isfahan's handicrafts } \\
\text { *Being functional of Isfahan's handicrafts } \\
\text { *Historical antiquity of Isfahan's handicrafts } \\
\text { *Being traditional, native and authentic of Isfahan's } \\
\text { handicrafts }\end{array}$ & $\begin{array}{l}\text { Weak points(W) } \\
\text { *Lack of appropriate and sufficient } \\
\text { advertisements } \\
\text { *Expensive raw materials and low quality } \\
\text { *Not continuing the handicrafts' profession } \\
\text { by new generation } \\
\text { *Avoid of art definitions and turning to } \\
\text { copying in production } \\
\text { *Lack of appropriate planning in the field of } \\
\text { production, business \& exports } \\
\text { *Time consuming of production \& as a result } \\
\text { lack of cash for producers }\end{array}$ \\
\hline $\begin{array}{l}\text { The opportunities: } \\
{ }^{*} \text { High potential of Isfahan in } \\
\text { attracting the tourists } \\
{ }^{\star} \text { Introducing the Isfahan as a } \\
\text { universal city of the handicrafts } \\
{ }^{*} \text { Creating markets of handicrafts in } \\
\text { the city } \\
\text { *The geographical center of Isfahan } \\
\text { city in the country } \\
{ }^{*} \text { Global reputation of cultural and } \\
\text { historical attractions of Isfahan city }\end{array}$ & $\begin{array}{l}\text { Offensive strategies (SO): } \\
\text { * Implementation of proceedings to introduce the } \\
\text { authenticity \& antiquity of Isfahan's crafts in the forms } \\
\text { of universal city programs of crafts } \\
\text { *Printing the books \& leaflet about presenting the } \\
\text { Isfahan's crafts in the field of universal city programs } \\
\text { of crafts } \\
\text { *Becoming of crafts' markets to a place to create } \\
\text { awareness of the originality \& applications of crafts }\end{array}$ & $\begin{array}{l}\text { Conservative strategies(WO): } \\
\star \text { *Various advertisements especially audio- } \\
\text { visual through universal city programs of } \\
\text { crafts } \\
\text { *Planning for creating activities in markets of } \\
\text { the city to flourish the crafts' market of } \\
\text { Naghsh Jahan squae } \\
\text { *Creating the possibility of pre buying for } \\
\text { major native \& foreign customers to create } \\
\text { the cash for producers }\end{array}$ \\
\hline 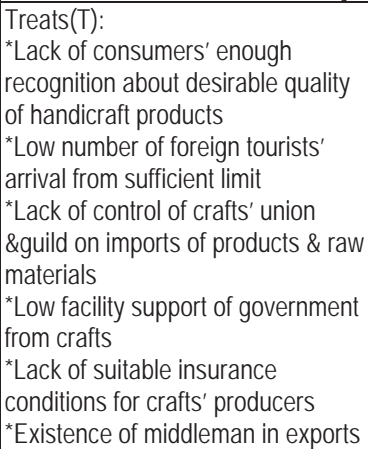 & $\begin{array}{l}\text { Competitive strategies (ST): } \\
\text { *Publication of antiquity, originality \& applicable of } \\
\text { crafts to tourists } \\
\text { *The mixture of ancient monuments advertising with } \\
\text { crafts to increase attracting the tourists } \\
\text { *Determining the suitable standards by Unions \& } \\
\text { Guilds for useful materials in crafts' production } \\
\text { *Holding the domestic \& foreign exhibitions to } \\
\text { informing the consumers of real poor quality } \\
\text { *Pre buying of products by government according to } \\
\text { making assure of high quality to solve the producers' } \\
\text { problem of cash }\end{array}$ & $\begin{array}{l}\text { Defensive strategies (WT): } \\
\text { *Giving loan by government to create cash } \\
\text { for producers } \\
\text { *Determining the copied products \& without } \\
\text { art originality to avoid their arrivals to the } \\
\text { market currency } \\
\text { *Dedicating subsidy for raw materials buying } \\
\text { *Informing the consumers of real suitable } \\
\text { quality of products by audio-visual \& print } \\
\text { media } \\
\text { *Planning \& modifying the hierarchy to low } \\
\text { effect of middlemen }\end{array}$ \\
\hline
\end{tabular}




\section{Discussion and Conclusion}

In the present study in terms of branding process of PCDL, it was proceed to create a brand for Isfahan's handicrafts. So that in the first step the position of Isfahan's handicrafts products in relation to competitors was determined by using the Walker's perceptible positioning technique, in the second step the brand's logo of this art presentation industry a well as the best ways of its advertising through determining of hierarchical tree were prioritized. In the next step the performance of different dimensions of Isfahan's handicrafts was measured. These dimensions derived from Balanced Score Card method are the dimensions of customer, internal processes, development and learning and financial. In the final step of branding by establishing of analysis matrix of SWOT, the strategic axes to enhance the brand value of Isfahan's handicrafts were presented. This study has not an absolute equivalent model inside and outside of the country. But the common modes with some of the researches can be examined. According to the research results it can be said that this research with the research results of Masoumi Zadeh et al (2013) is aligned in terms of that both researches focus on local product of country including saffron and handicrafts and in both researches the branding practice is done through matrix analysis of SWOT. Also this research with the research of Shojaee and Hosseini (2013) is consistent. The named research during the branding operation for the automotive industry has considered the concept of brand's communication and advertising that is coordinated with the present research. On the other dimension can be noted that the present research is somehow the continuation of the results of two other researches and support from the performance of this research. The study of Khorasani Zadeh and Mehrabi (2012) in their results indicated to the role of Isfahan's handicrafts in economic and tourism development. This research focuses on planning for handicrafts in order to increase the income and tourists arrival that can be a basis to justify this study. Also Sarrami (2005) emphasized on solving the problems about handicrafts in his research output that subject support the performance of this study.

\section{Research Suggestions}

It is suggested to establish a long-term interactive between the directions of the Isfahan's cultural heritage and Isfahan's handicrafts' unions and guilds on one hand and the National Broadcasting Organization on the other hand for advertising and programs related to handicrafts. It's recommended that the Isfahan's handicrafts' unions and guilds to design the quality standard sign for these products and the development of spin-quality products especially in terms of export should be avoided. It's recommended to Cultural Heritage and Tourism Organization of Iran to hold international exhibitions of handicrafts at home and abroad. It's recommended that these exhibitions to be held on the International Day of handicrafts around the time of $20^{\text {th }}$ khordad (10 June). Also it's suggested that these exhibitions to be mixed with the content of originality and practical of these products. It's recommended to handicrafts' producers to try to refresh and update the use of Isfahan's handicrafts in the form of the most useful tools in daily living. This proposal is done by identifying the custom and culture of the Islamic and the West countries and considering to the individuals' tastes in a more suitable mode.

\section{References}

Blech, G \& Blech, MA. 2001, Advertising and Promotion, Mc.Graw-Hill, New York.

Theo bald, W. F. (2005). Global tourism. Elsevier Inc, USA.

Bendixen, M., Bukasa, K.A., and Abratt, R.A. 2004. Brand equity in the business-tobusiness market. Industrial Marketing Management, 33(5): $371-380$.

Ghodeswar, M.B. (2008). Building brand identity in competitive markets: a conceptual model. Journal of Product\& Brand Management, 7 (1): 4-12.

Hair, J., Bush, R. \& Ortinau, D. (2002). "Marketing research: Within a changing information environment", 2rd edition, Megraw Hill/ Irwin Series in Marketing, pp. 10-221.

Holt, D. B., 2015. Brands and Branding. Cultural Strategy Group. [online]Available onhttp://testconso.typepad.com/files/brands-andbrandingcsg2. Pdf

Kaplan, R. S., and D. P. Norton., 1996. Using the Balanced Scorecard as a Strategic Management System: Harvard Business Review, Jan-Feb: 47-59.

Kotler, Ph.,Keller, K. L., Koshy, A., Jha, M., 2013. Marketing Management: A South AsianPerspective, 14thEdition.Imprint PearsonEducation, 2013, 728 p.ISBN 9788131767160.

Ibrahimi, Abdolhamid, Ghaderi, Ismaeel, Gayder Rahmati, Sefr \& Akbari Reza (2010), examining the effect of advertisements to attract the tourists, geography \& development, number8, 139-156

Asgharpour, Mohammad Javad (2011), multi-criteria decision making, Tehran University publication, tenth edition, Tehran

Walker, Harper, John Mullins, John CL, marketing strategy with decision-oriented approach, translation of Mohammad Izadi (2013), 
publications of cultural research bureau, Tehran

Haghighi, Mohammad, Taher, Ali (2015), investigating the problems and obstacles of the development of tourism industry in Isfahan from tourists'viewpoint, business administration faculty of management, Tehran University, volume7, issue4, pages 865-880

Hamidi Zadeh, Mohammad Reza, Yazdani, Naser (2011), strategic model for E-ads consumer behavior, exploration of business administration, quarterly, issue6, pages of 150-176

Darzban Azizi, Abdolhadi, Rahimi, Elahe (2015), investigating the effect of advertising and sales promotion on the creation of brand equity, business management of Tehran Universiti, volume7, number3, pages642-664

Love lock, Wright (2006), principles \&management of services' marketing, Bahman Forouzandeh of learned publication, Isfahan, first print, 188-190.

Masoumzadeh Zavareh, Abolfazl, Ebrahimi, Jafar Dehnavi, Khalil (2013), Operational program of product branding of Iran's saffron, journal of agriculture and technology, volume1, issue2, pages39-68

Maleki Minbash, Morteza, mehdi, hossein, Baghani, Ali (2015), examining the impact of brand's dimensions of services on loyalty to brand in the banking industry, journal of modern marketing researches, fifth year, number19, pages119-138.

Mohed, Ali, Amanpour, Naderi, Kaveh (2011), urban tourism marketing based on brand finding with the Analytical Hierarchy Process model, specialized scientific journal of spatial planning, first year, third number, pages17-36.

Honarfar, (1977), Isfahan, JB publication, Tehran

Yavari, Hossein (2011), Iran's crafts recognition, sixth print, Hamkameh publications, Tehran.

Halvard (2013), industrial marketing, Nikoomaram translation, Hashem, Abdolvand, Mohammad Ali, Islamic Azad University publications, (2013). 